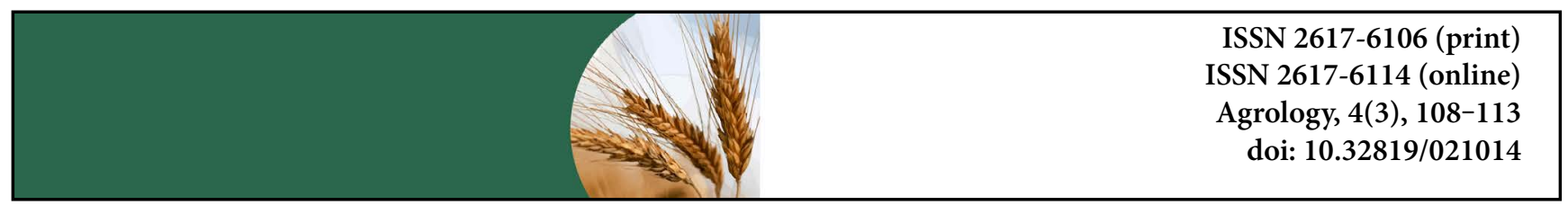

\section{Original researches}

Received: 12 June 202

Revised: 25 June 2021

Accepted: 26 June 2021

Dnipro State Agrarian and Economic University Serhiy Yefremov Street, 25,

49000, Dnipro, Ukraine

Tel.: +38-066-559-54-63

E-mail: glub@ukr.net

Cite this article: V.M. Lovynska, S.A.

Sytnyk, V.I. Chorna, K.P. Maslikova. (2021) Dynamic bioproductivity of Scots pine stands within Northern Steppe of Ukraine conditions. Agrology, 4(3), 108-113. doi: 10.32819/02101

\title{
Dynamic bioproductivity of Scots pine stands within Northern Steppe of Ukraine conditions
}

\author{
V.M. Lovynska, S.A. Sytnyk, V.I. Chorna, K.P. Maslikova \\ Dnipro State Agrarian and Economic University, Dnipro, Ukraine
}

\begin{abstract}
Dynamic changes in forest ecosystems, which can be both short-term and longterm, are assessed on the scale of long-term biologically determined stages, through the determination of age parameters. In this context, the results on the dynamic changes of the components of the aboveground phytomass of Scots pine in the northern steppe zone of Ukraine are presented. Based on the simulated growth tables of the studied modal artificial pine stands, standards for the dynamics of their bioproductivity have been developed for such components of aboveground phytomass as trunk in bark, branches in bark and needles. Modeling and statistical evaluation to determine the phytomass of the aboveground part of the pine stand: wood and bark of the trunk, branches and needles of the crown in a completely dry state. Tables of theoretical distribution of indicators of components of phytomass of pines for an age category from 10 to 80 years are constructed. Regularities of phytomass changes of trunk components in bark and crown for stands of IIV classes of quality were found. It is established that the dynamics of changes in the components of both the stem part and the components of the crown is characterized by a gradual increase in phytomass with age. The trend of dynamic changes is similar for all studied rating classes. It is obvious that stands of the first quality have the highest productivity of the studied classes. Decreased creditworthiness is accompanied by a gradual decline in productivity. It is investigated that the most significant differences in the phytomass parameters of different qualities are characteristic of older stands. It is calculated that the phytomass of the trunk in the bark varies from $5.4 \mathrm{t} / \mathrm{ha}$ (10 years) to $144 \mathrm{t} / \mathrm{ha}$ (80 years), and the nature of changes in the phytomass of the crown with age actually reflects the trend of phytomass dynamics of branches compared to pine. A comparative assessment of the dynamic changes of phytomass components of pine stands of the northern steppe part with the results of bioproductivity of pines of Ukrainian Polissya and Forest-Steppe, forest-steppe and northern-steppe regions of the European part, Kazakhstan and Siberia is given. On the basis of the received tables of dynamic changes of bioproductive processes in pines of the Northern Steppe the theoretical substantiation of practical use of normative-reference material for conditions of steppe part of Ukraine is made. The obtained results provide an opportunity to assess the current state of pine forests in the study region and predict the dynamics of their changes, which will allow the objective implementation of forestry measures, taking into account the regional peculiarities of pine formation.
\end{abstract}

Keywords: Pinus sylvestris L.; relative height; modeling; components of aboveground phytomass; dynamic changes.

\section{Моделювання динаміки біопродуктивності деревостанів сосни звичайної в умовах Байрачного Степу України}

В.М. Ловинська, С.А. Ситник, В.І. Чорна, К.П. Маслікова

Дніпровський державний аграрно-економічний університет, Дніпро, Україна

Анотація. Динамічні зміни в лісових екосистемах, які можуть бути як короткочасними, так і тривалими, оцінюються в масштабах багаторічних біологічно обумовлених стадій, через визначення співвідношень вікових параметрів. Зіставлення таблиць біологічної продуктивності з таблицями ходу росту дозволяє спрогнозувати закономірності формування біологічної продукції деревостанів 3 практичним застосуванням результатів досліджень під час розрахунків розміру лісокористування. У такому контексті представлено результати щодо динамічних змін компонентів надземної фітомаси сосни звичайної в умовах північностепової зони України. Визначення закономірностей динамічних змін надземної фітомаси деревостанів сосни звичайної проведено на базі попередньо змодельованого ходу росту. Експериментальні дані отримано шляхом обробки матеріалів повидільної бази даних, що містять 4016 видів штучних насаджень сосни звичайної та 25 тимчасових пробних площ лісових культур сосни, які функціонують в умовах Дніпропетровського регіону. На основі змодельованих таблиць ходу росту досліджуваних модальних штучних соснових деревостанів розроблено нормативи динаміки їх біопродуктивності для таких компонентів надземної фітомаси, як стовбур у корі, гілки в корі та хвоя. Змодельовано та статистично оцінено ма- 
тематичні моделі для розрахунку фітомаси надземної частини соснового деревостану: деревини та кори стовбура, гілок та хвої крони у абсолютно сухому стані. Побудовано таблиці теоретичного розподілу показників компонентів фітомаси сосняків для вікової категорії від 10 до 80 років. Знайдено закономірності змін фітомаси компонентів стовбура в корі та крони для деревостанів I-IV класів бонітету. Встановлено, що динаміка змін компонентів, як стовбурової частини, так і компонентів крони, характеризується поступовим наростанням фітомаси з віком. Тренд динамічних змін $є$ подібним для всіх досліджуваних бонітувальних класів. Очевидно, що найвищу продуктивність із досліджуваних класів мають деревостани I бонітету. Зниження бонітету супроводжується поступовим спаданням продуктивності. Досліджено, що найбільш суттєві відмінності в показниках фітомаси різних бонітетів характерні для деревостанів старшого віку. Розраховано, що фітомаса стовбура в корі змінюється від 5,4 т/га (10 років) до 144 т/га (80 років), а характер зміни фітомаси крони 3 віком фактично відбиває тенденцію динаміки фітомаси гілок порівняно з хвоєю. Наведено порівняльне оцінювання динамічних змін компонентів фітомаси соснових деревостанів північно-степової частини з результатами біопродуктивності сосняків Українського Полісся і Лісостепу, лісостепових та північно-степових регіонів Європейської частини, Казахстану та Сибіру. На основі отриманих таблиць динамічних змін біопродукційних процесів у сосняках Північного Степу надано теоретичне обгрунтування практичного використання нормативно-довідкового матеріалу для умов степової частини України. Отримані результати створюють можливості оцінювати сучасний стан соснових лісів досліджуваного регіону та прогнозувати динаміку їх змін, що дозволить об’єктивно здійснювати лісогосподарські заходи, з урахуванням регіональних особливостей формування сосняків.

Ключові слова: Pinus sylvestris L.; відносна висота; моделювання; компоненти надземної фітомаси; динамічні зміни.

\section{Вступ}

Усі процеси, які відбуваються нині під впливом навколишнього середовища, є активними інтенсифікаторами динамічних змін карбону в лісових насадженнях (García, 2008; Burkhart \& Tomé, 2012). Двоокис вуглецю є змінною, у високому ступені залежною від факторів різної етіології (Kurz \& Apps, 1999; Amiro et al., 2001; Kurz et al., 2008; Li et al., 2017), а найважливішим фактором, який визначає кумулятивний процес формування вуглецевого бюджету, є кількість накопиченої в умовах лісової формації фітомаси (Houghton, 1997; Pan et al., 2011). У зв'язку із цим значна кількість сучасних досліджень спрямована на визначення існуючого стану, а також встановлення прогнозованих динамічних змін біопродукційних процесів складових компонентів лісових ценозів (Usoltsev, 1988; Petrenko \& Lakyda, 2000; Powella et al., 2010).

Нормативи, що описують ріст насаджень, спрямовані в переважній своїй кількості для опису так званих «нормальних» деревостанів, які $є$ чистими за своїм складом, мають високу повноту та продуктивність (Miklush, 2008). Однак таких деревостанів стає все менше, а отже, виникає потреба в опису існуючого стану деревостанів, який обумовлюється впливом навколишнього середовища. Такі деревостани отримали назву модальних (реальних) і за ступенем зімкненості зазвичай мають середню повноту.

Саме кількісне визначення біопродукційних процесів деревостанів $\epsilon$ важливою складовою під час встановлення загальної біосферної ролі лісів, з причини потреби розрахунку повного вуглецевого бюджету (Prince \& Goward, 1995; Slayback et al., 2003; Reich \& Oleksyn, 2008; Seidel et al., 2013). I вирішення даного завдання вимагає встановлення вікової динаміки компонентів фітомаси (в одиницях абсолютно сухої речовини), зокрема, надземної, яка традиційно не визначається в режимі лісовпорядкування. На додаток до цього, “накладання” таблиць біологічної продуктивності на таблиці ходу росту дозволяє спрогнозувати закономірності формування біологічної продукції деревостанів $з$ практичним застосуванням результатів досліджень під час розрахунків розміру лісокористування (Usoltsev, 1985; Weiskittel et al., 2011; Lakida et al., 2012).

Динаміка лісонасаджень має певні особливості та визначається комплексом чинників, головним 3 яких є біологічні особливості виду, тобто специфіка їх онтогенетичних змін у процесі росту деревостану (Bala, 2002; Terentyev et al., 2008; Powella et al., 2010). Однак в умовах розвитку та формуван- ня насадження, насамперед штучного походження, одним із найбільш вирішальних факторів динамічних змін деревостану стає господарська діяльність людини (Pretzsch, 2009; Perot \& Picard, 2012; Pretzsch et al., 2015).

Існуючі нормативи біопродукувальних процесів створені для різних районів України, однак вони не можуть бути уніфікованими та відображати особливості ростових процесів конкретних регіонів, зокрема, зони Байрачного Степу України (Дніпропетровська область). Унаслідок цього вельми актуальним питанням постає визначення специфіки росту та біопродуктивних процесів соснових деревостанів у сучасних умовах досліджуваного регіону з розробкою відповідних таблиць.

Мета нашого дослідження передбачала встановлення закономірностей динаміки біопродукційних показників надземної фітомаси модальних соснових деревостанів, які зростають в умовах Байрачного Степу України.

\section{Матеріал і методи}

Дослідження 3 визначення динамічних змін надземної фітомаси сосняків проводили на основі змодельованого їх ходу росту на базі отриманих експериментальних даних 3 25 тимчасовими пробними площами (ТПП) лісових культур сосни та шляхом обробки матеріалів повидільної бази даних, що містить 4016 виділів штучних насаджень сосни звичайної, які функціонують в умовах Дніпропетровського регіону. Попередньо проведено аналіз оцінки площ та запасів сосняків і визначено переважання деревостанів сосни штучного походження у чотири рази $(82,9 \%$ від загальної площі соснових деревостанів) порівняно з природними. Тому лісові культури обрано як базу для побудови таблиць біопродуктивності сосняків в умовах Байрачного Степу та їхнього порівняння 3 даними інших авторів.

У цілому процес розроблення нормативно-довідкових таблиць біопродуктивності соснових насаджень Байрачного Степу включав такі етапи: збір, оброблення та аналіз дослідних даних; моделювання таксаційних показників соснових деревостанів; моделювання біопродуктивності компонентів надземної фітомаси, перевірка моделей та їх верифікація (Lakyda, 2002; Lakyda \& Vasylyshyn, 2016).

Під час моделювання динаміки компонентів фітомаси культур сосни звичайної в умовах Північного Степу, як однієї 3 незалежних змінних, використана відносна повнота деревостану. Відносна повнота деревостану в кожний досліджу- 
V.M. Lovynska, S.A. Sytnyk, V.I. Chorna, K.P. Maslikova

Dynamic bioproductivity of Scots pine stands within Northern Steppe of Ukraine conditions

ваний віковий період (5 років) розрахована за відношенням суми площ поперечного перерізу фактичного і “нормального" насадження, у якому відносна повнота приймається за одиницю.

Моделювання і перевірку моделей на статистичну значущість проводили для таких компонентів фітомаси деревостану: деревина та кора стовбура, гілки та хвоя крони в абсолютно сухому стані.

Для апроксимації експериментальних даних при побудові регресій використовували алометричне рівняння ступеневого вигляду, яке зазвичай вирізняється рядом переваг під час опису біологічних систем (Kofman, 1986). Побудова, підбір, оцінювання моделей у процесі регресійного аналіз виявили найбільш придатними для розрахунку фракцій фітомаси трифакторні моделі зі залученням, як незалежні змінні, таксаційних показників: вік (A), середній діаметр (D), середня висота $(\mathrm{H})$ та відносна $(\mathrm{P})$ й абсолютна $(\mathrm{G})$ повноти насадження.

Таблиця 1. Моделі для розрахунку фракцій надземної фітомаси культур сосни звичайної та їх статистична оцінка

\begin{tabular}{|lcccccc|}
\hline \multirow{2}{*}{ Фракція фітомаси } & Вид залежності & \multicolumn{5}{c|}{ Статистики оцінки рівнянь } \\
\cline { 3 - 6 } & & $R^{2}$ & $F_{\text {факт }}$ & $F_{\text {крит }}$ & \multicolumn{2}{c|}{ залишків } \\
\hline Деревина стовбура & $P h_{\text {дер. }}=1,986 \cdot D^{0,072} \cdot H^{1,332} \cdot \mathrm{P}^{0,940}$ & 0,83 & 39,30 & 3,24 & $-1,257$ & 2,056 \\
Кора стовбура & $P h_{\text {кори }}=0,738 \cdot D^{-0,180} \cdot H^{1,336} \cdot \mathrm{P}^{1,846}$ & 0,69 & 15,04 & 3,24 & 0,697 & 0,160 \\
Гілки в корі & $P h_{\text {гіл. }}=0,0002 \cdot \mathrm{A}^{1,236} \cdot G^{1,604}$ & 0,53 & 12,93 & 3,59 & $-0,318$ & 0,240 \\
Хвоя & $P h_{\text {хв. }}=0,032 \cdot H^{-0,467} \cdot G^{1,867}$ & 0,53 & 17,63 & 3,59 & 0,232 & 0,666 \\
\hline
\end{tabular}

Таблиця 2. Динаміка компонентів надземної фітомаси модальних штучних соснових деревостанів I класу бонітету Байрачного Степу України

\begin{tabular}{|c|c|c|c|c|c|c|c|c|c|c|c|c|c|}
\hline \multirow{3}{*}{ 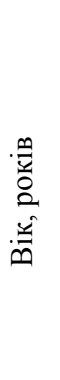 } & \multirow{3}{*}{ 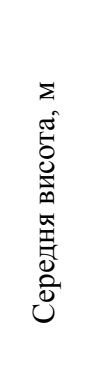 } & \multirow{3}{*}{ 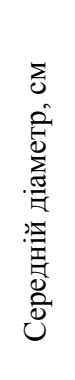 } & \multirow{3}{*}{ 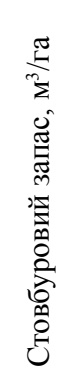 } & \multicolumn{7}{|c|}{$\begin{array}{c}\text { Фітомаса в абсолютно сухому стані, } \\
\text { т/га }\end{array}$} & \multirow{3}{*}{ 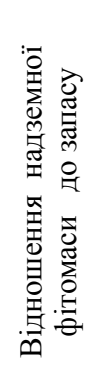 } & \multirow{2}{*}{\multicolumn{2}{|c|}{$\begin{array}{c}\text { Продукція } \\
\text { фітомаси, } \\
\text { т/га/рік }\end{array}$}} \\
\hline & & & & & стовбурі & & & крон & & & & & \\
\hline & & & & 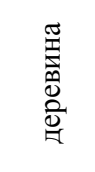 & 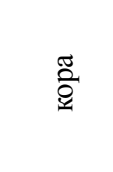 & 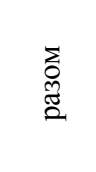 & 紊 & $\begin{array}{l}\text { पू } \\
\text { 恖 }\end{array}$ & 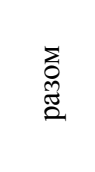 & 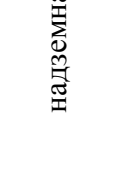 & & 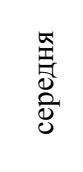 & 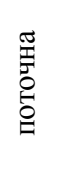 \\
\hline 10 & 1,7 & 2,8 & 4 & 4,3 & 1,2 & 5,4 & 0,01 & 0,09 & 0,10 & 5,53 & 1,57 & 0,55 & - \\
\hline 15 & 3,6 & 5,0 & 18 & 9,4 & 1,8 & 11,2 & 0,10 & 0,48 & 0,58 & 11,74 & 0,64 & 0,78 & 1,24 \\
\hline 20 & 5,9 & 7,5 & 48 & 16,1 & 2,4 & 18,5 & 0,38 & 1,21 & 1,59 & 20,07 & 0,42 & 1,00 & 1,67 \\
\hline 25 & 8,3 & 10,1 & 88 & 26,6 & 3,8 & 30,4 & 0,89 & 2,06 & 2,95 & 33,36 & 0,38 & 1,33 & 2,66 \\
\hline 30 & 10,6 & 12,6 & 131 & 40,2 & 5,8 & 46,0 & 1,62 & 2,81 & 4,42 & 50,42 & 0,38 & 1,68 & 3,41 \\
\hline 35 & 12,9 & 15,1 & 172 & 53,1 & 7,5 & 60,6 & 2,47 & 3,36 & 5,83 & 66,42 & 0,39 & 1,90 & 3,20 \\
\hline 40 & 15,0 & 17,5 & 208 & 65,0 & 8,7 & 73,7 & 3,38 & 3,72 & 7,10 & 80,75 & 0,39 & 2,02 & 2,87 \\
\hline 45 & 16,9 & 19,7 & 238 & 76,7 & 9,9 & 86,6 & 4,30 & 3,93 & 8,23 & 94,84 & 0,40 & 2,11 & 2,82 \\
\hline 50 & 18,6 & 21,9 & 263 & 87,7 & 11,0 & 98,7 & 5,22 & 4,05 & 9,26 & 107,96 & 0,41 & 2,16 & 2,62 \\
\hline 55 & 20,1 & 23,9 & 283 & 97,1 & 11,9 & 108,9 & 6,12 & 4,09 & 10,21 & 119,15 & 0,42 & 2,17 & 2,24 \\
\hline 60 & 21,4 & 25,8 & 299 & 106,1 & 12,7 & 118,8 & 7,00 & 4,10 & 11,10 & 129,87 & 0,43 & 2,16 & 2,14 \\
\hline 65 & 22,6 & 27,6 & 312 & 113,8 & 13,3 & 127,1 & 7,87 & 4,09 & 11,96 & 139,04 & 0,45 & 2,14 & 1,83 \\
\hline 70 & 23,6 & 29,3 & 322 & 120,1 & 13,7 & 133,8 & 8,73 & 4,06 & 12,79 & 146,60 & 0,46 & 2,09 & 1,51 \\
\hline 75 & 24,5 & 30,9 & 330 & 125,4 & 14,1 & 139,5 & 9,58 & 4,03 & 13,62 & 153,08 & 0,46 & 2,04 & 1,30 \\
\hline 80 & 25,2 & 32,4 & 337 & 129,7 & 14,2 & 143,9 & 10,44 & 4,00 & 14,44 & 158,38 & 0,47 & 1,98 & 1,06 \\
\hline
\end{tabular}




\section{Результати}

Моделювання та перевірку моделей на статистичну значущість проводили для таких компонентів фітомаси деревостану: деревина та кора стовбура, гілки та хвоя крони в абсолютно сухому стані (табл. 1).

Як показала статистична оцінка отриманих моделей, компоненти фітомаси стовбура описуються регресійними рівняннями з високим рівнем апроксимації. Дещо нижчими за коефіцієнтом детермінації, але значущими на 5\%-вому рівні, характеризуються рівняння залежності компонентів крони.

На основі отриманих моделей побудовано таблиці теоретичного розподілу змодельованих показників компонентів фітомаси в період від 10 до 80 років (табл. 2). Калькуляцію динаміки накопичення складових біопродукційного процесу проведено на рівні деревостану з визначенням акумуляції біомаси на 1 га в період за 5 років. Сумарну величину надземної фітомаси деревостану розраховували шляхом додавання його складових - стовбура в корі та крони.

Закономірності змін біопродукційних показників компонентів стовбура в корі та крони для деревостанів деяких класів бонітету (I-IV) ілюструє рис. 1. Динаміка змін компонентів стовбурової частини $є$ досить узгодженою і подібною для досліджуваних класів бонітету, вирізняючись поступовим наростанням фітомаси з віком. Найвищою продуктивніс- тю 3 представлених класів характеризуються деревостани I бонітету; зі зниженням бонітету продуктивність спадає, що найбільшою мірою характерно для деревостанів більш старшого віку (рис. $1, a)$.

Схожа закономірність інтенсифікації біопродукційних процесів властива і гілкам з відповідним наростанням фітомаси з віком та обернено пропорційна збільшенню класу бонітету (рис. 1,б). Величина запасів фітомаси гілок змінюється в межах 0,01-10,4 т/га. На відміну від стовбурової частини та фітомаси гілок, для компоненти асиміляційної частини крони (хвої) у деревостанах бонітетів вищих класів (I та II) простежується варіювання фітомаси з досягненням максимуму у 60 (I клас) та 70 (II клас) років, після чого визначена тенденція на спадання пошукової величини (рис. 1, в).

Для обох компонентів крони не зафіксовано істотного варіювання значень їх фітомаси в межах представлених класів бонітету. Наприклад, величина фітомаси гілок для 80-річних деревостанів I-IV класів бонітету знаходиться в межах від 8,1 до 10,1 т/га, а значення фітомаси хвої - від 3,8 до 4,0 т/га. У цілому характер зміни загальної фітомаси крони з віком здебільшого відбиває тенденцію накопичення фітомаси гілок, частка яких, порівняно з компонентом хвої, $є$ більшою ніж удвічі.

Продукція органічної маси $є$ характеристикою, яка відображає стан та особливості функціонування лісів у тих чи інших умовах. Середня продукція фітомаси за запасом ростучо-

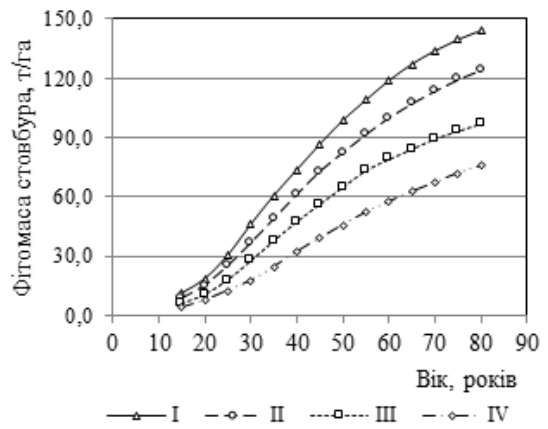

$\sigma$

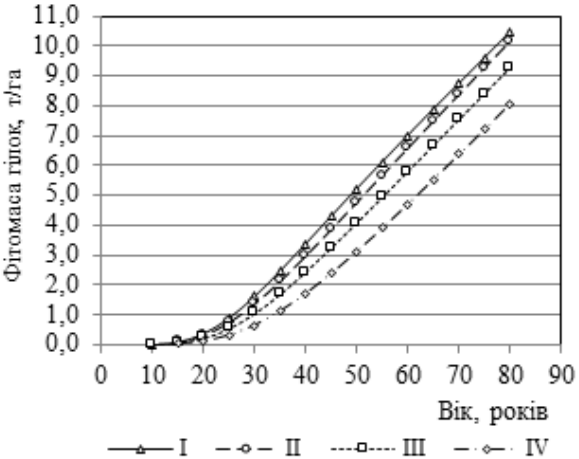

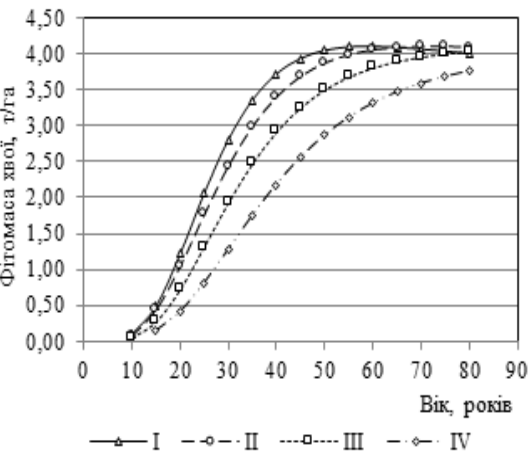

Рис. 1. Динаміка зміни обсягів компонентів стовбура (a), крони (б) та надземної фітомаси (в) соснових деревостанів за класами бонітету

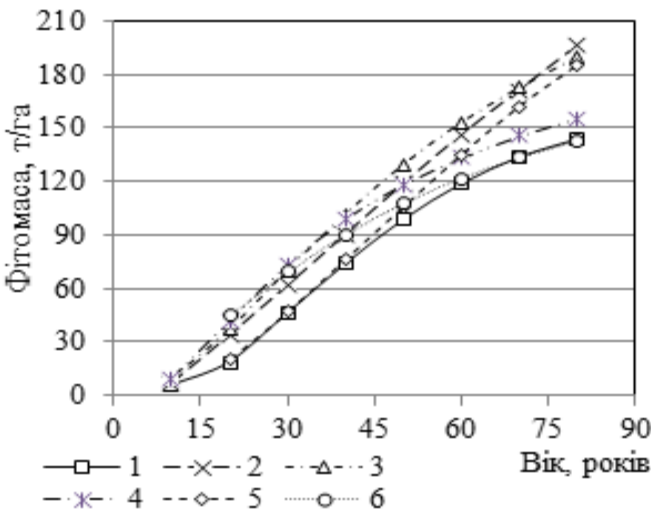

6

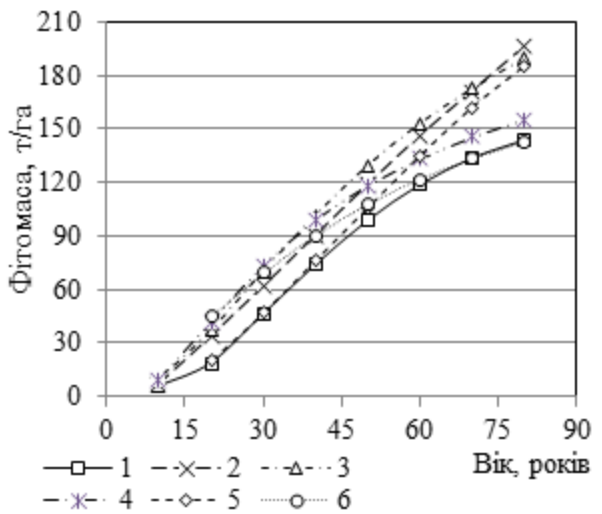

Рис. 2. Порівняння динаміки фітомаси стовбура в корі (a) та крони (б) соснових деревостанів:

1 - результати досліджень; 2 - оптимальні штучні деревостани Полісся України; 3 - модальні штучні деревостани Полісся України; 4 - модальні штучні деревостани Лісостепу України; 5 - нормальні соснові деревостани Казахстану і Сибіру; 6 - модальні культури сосни в лісостепових і північно-степових екорегіонах європейської частини 
го деревостану досліджуваних соснових лісів I класу бонітету становить 0,6-1,7 т/га/рік; поточна зміна фітомаси варіює від 1,4 до 3,4, тобто в середньому дорівнює 2,2 т/га/рік.

\section{Обговорення}

Під час перевірки відповідності побудованих нормативів найчастіше вдаються до порівняльного аналізу з іншими нормативами, складеними для досліджуваного об'єкта. Для порівняльної оцінки динаміки фітомаси компонентів надземної частини сосняків досліджуваного регіону використано дані щодо біопродуктивності соснових деревостанів Українського Полісся і Лісостепу, лісостепових та північно-степових регіонів Свропейської частини, Казахстану та Сибіру (рис. 2).

Як виявив порівняльний аналіз динаміки біопродуктивності стовбурів, у Північному Степу України процес накопичення фітомаси соснових деревостанів відбувається повільніше й у значно меншому об'ємі порівняно з іншими досліджуваними регіонами. Найближчі до отриманих даних значення показників стовбурової частини зареєстровано для модальних штучних деревостанів сосни лісостепових і північно-степових екорегіонів європейської частини. Максимальні відхилення фітомаси стовбурів з різницею від $-44 \%$ (10 років) до $-34 \%$ (80 років) зафіксовано порівняно 3 модальними деревостанами сосни Полісся України (Petrenko \& Lakyda, 2000).

Що стосується значень фітомаси показників крони, то загальна тенденція поступового наростання означеного показника з віком деревостанів $€$ тотожною лише для оптимальних культур сосни Полісся України та модальних культур сосни в лісостепових і північно-степових екорегіонах європейської частини. Для інших оцінюваних регіонів тренд накопичення сумарної фітомаси гілок та хвої сосняків зареєстровано в основному до 70-річного віку, після чого фітомаса дещо спадає.

Порівняння розроблених нормативів модальних деревостанів Північного Степу і нормативів динаміки біологічної продуктивності модальних деревостанів культур сосни Полісся, Лісостепу України свідчить про меншу біопродуктивність у регіоні досліджень. Різниця в запасах фітомаси до 80 -річного віку становить $12 \%$ - Полісся, $14 \%$ - Лісостеп і $20 \%$ - лісостепові та північно-степові екорегіони європейської частини.

Отримані дані щорічної продукції фітомаси відрізняються від результатів, наведених для деревостанів культур сосни в інших регіонах України. Так, для зони Українського Полісся середній показник поточного приросту (Terentyev et al., $2008)$, порівняно з отриманими нами даними, є вищим на $30 \%$ (3 т/га/рік) та на 22\% (2,7 т/га//рік-1) порівняно 3 даними по Лісостепу (Shvidenko et al., 2008; Pasternak et al., 2014). Відмінність в отриманих результатах пояснюється специфічністю умов місцезростання насаджень, особливостями грунтових та погодних умов у різних кліматичних зонах, а також варіюванням методологічних підходів під час визначення показників біопродукційних процесів у досліджуваних деревостанах.

За визначенням деяких авторів (Usoltsev, 1985), в умовах Степу зазвичай відбувається раннє розімкнення соснових культур, однією з причин якого називають вуглецеве голодування як результат невідповідності між синтезом органічної речовини та іiі витрачанням на посилене дихання. Натомість, 3 огляду на існуючу на сьогодні інформацію щодо степового лісорозведення, загущені лісопосадки характеризуються більш високою стійкістю до несприятливих факторів зовнішнього середовища, однак у таких умовах вони $€$ менш продуктивними.

\section{Висновки}

Середні загальні запаси надземної фітомаси зростаючих соснових деревостанів 80-річного віку Дніпропетровського регіону, залежно від класів бонітету, варіюють від 32,4 (V клас бонітету) до 89,3 т/га (І клас бонітету). Основна частина надземної фітомаси формується стовбуровою їі частиною і становить майже 90\%. Запаси фітомаси асимілюючих органів досягають 5,7-9,0 т/га, і зі збільшенням віку деревостану частка фітомаси крони зменшується. Запропоновані таблиці динаміки біопродуктивності соснових деревостанів $є$ першим лісотаксаційним нормативом подібного типу для умов Північного Степу України; за допомогою таблиць можливою стала оцінка особливостей формування надземної фітомаси лісонасаджень сосни залежно від лісорослинних умов та бонітувальних класів.

У подальшому дослідження динаміки біопродукувальних процесів у деревостанах сосни звичайної триватимуть у контексті встановлення їх вуглецедепонувальної та киснепродукувальної здатності в розрізі вікових змін.

\section{References}

Amiro, B. D., Todd, J. B., Wotton, B. M., Logan, K. A., Flannigan, M. D., Stocks, B. J., Mason, J. A., Martell, D. L. \& Hirsch, K. G. (2001). Direct carbon emissions from Canadian forest fires, 1959-1999. Canadian Journal of Forest Research, 31, 512-525. doi: 10.1139/cjfr-31-3-512

Bala, O. P. (2002). Modeling of growth forecast by average height in artificial oak plantations of Ukraine. Scientific Bulletin of NAU, 54, 219-224.

Burkhart, H. E., \& Tomé, M. (2012). Modeling Forest Trees and Stands. Springer. doi: 10.1007/978-90-481-3170-9

García, O. (2008). Visualization of a general family of growth functions and probability distributions - the growth-curve explorer. Environmental Modelling Software, 23(12), 14741475. doi:10.1016/j.envsoft.2008.04.005

García, O., Burkhart, H.E., \& Amateis, R.L. (2011). A biologically-consistent stand growth model for loblolly pine in the Piedmont physiographic region, U.S.A. Forestry Ecological and Management, 262(11), 2035-2041. doi:10.1016/j. foreco.2011.08.047

Houghton, J. T. (1997). Global warming: the complete briefing. Cambridge: Cambridge University Press.

Kofman, G. B. (1986). Growth and shape of trees. Novosibirsk: Science (in Russian).

Kurz, W. A., \& Apps, M. J. (1999). A 70-year retrospective analysis of carbon fluxes in the Canadian forest sector. Ecological Applications, 9, 526-547. doi: 10.1890/10510761(1999)009[0526:AYRAOC]2.0.CO;2

Lakida, P. I., Terentyev, A. Yu., \& Vasilishin, R. D. (2012). Artificial pine stands of Polissya of Ukraine - forecast of growth and productivity. Kyiv, Maidachenko I.S.

Lakyda, I. P., \& Vasylyshyn, R. D. (2016). Methodological background for development of a system of growth and productivity models for stands of the main forest-forming tree species of Ukraine. Forestry and Forest Melioration, 129, 3-9. Retrieved from http://forestryforestmelioration.org.ua/index. $\mathrm{php} /$ journal/article/view/104

Lakyda, P. I. (2002). Phytomass of Ukrainian Forests. Ternopil, Zbruch Ltd. 256 (in Ukrainian).

Li, P., Peng, Ch., Wang, M., Li, W., Zhao, P., Wang, P., Yang, Y., Zhu, Q. (2017). Quantification of the response of global terrestrial net primary production to multifactor global change. Ecological Indicators, 76, 245-255. doi: 10.1016/j.ecolind.2017.01.021 
Miklush, S. I. (2008). Growth models of plain beech stands. Scientific Bulletin of NLTU, 18(11), 122-133.

Pan, Y., Birdsey, R. A., Fang, J., Houghton, R., Kauppi, P. E., Kurz, W. A., ... \& Hayes, D. (2011). A large and persistent carbon sink in the World's forests. Science, 333, 988-993. http://dx.doi.org/10.1126/science.1201609

Pasternak, V. P., Nazarenko, V. V., \& Karpets, Yu. V. (2014). Qualitative characteristics of Scots pine wood and phytomass of pine forests of the Forest-Steppe of Kharkiv region. Forestry and Forest Melioration, 125, 55-60.

Perot, T, \& Picard, N. (2012). Mixture enhances productivity in a two species forest: evidence from a modeling approach. Ecologycal Resources, 27(1), 83-94.

Petrenko, M. M., \& Lakyda, P. I. (2000). Research of phytomass dynamics of pine cultures of Ukrainian Polissya. Scientific Bulletin of NAU, 25, 339-345.

Powella, S. L., Cohenb, W. B., Healeyc, S. P., Kennedyd, R. E., Moisenc, G. G., Piercee, K. B., \& Ohmannb, J. L. (2010). Quantification of live aboveground forest biomass dynamics with Landsat time-series and field inventory data: a comparison of empirical modeling approaches. Remote Sensing of Environment, 114(5), 1053-1068. https://doi. org/10.1016/j.rse.2009.12.018

Pretzsch, H. (2009). Forest dynamics, growth and yield. From measurement to model. Springer, Berlin.

Pretzsch, H., Forrester, D.I., Ro“tzer, Th. (2015). Representation of species mixing in forest growth models. A review and perspective. Ecological Modeling. doi:10.1016/j. ecolmodel.2015.06.044

Prince, S. D., \& Goward, S. N. (1995) Global primary production: a remote sensing approach. Journal of Biogeography, 22, 815835. https://doi.org/10.2307/2845983

Reich, P.B., \& Oleksyn, J. (2008) Climate warming will reduce growth and survival of Scots pine except in the far north. Ecology Letters, 11, 588-597. https://doi.org/10.1111/j.14610248.2008.01172.x
Seidel, D., Leuschner, C., Scherber, C., Beyer, F., Wommelsdorf, T., Cashman, M.J., Fehrmann, L. (2013). The relationship between tree species richness, canopy space exploration and productivity in a temperate broad-leaf mixed forest. Forest Ecology and Management, 310, 366-374. doi: 10.1016/j. foreco.2013.08.058

Shvidenko A. Z., Schepachenko D. G., Nilsson S., Boluy Yu. I. (2008). Tables and models of the course of growth and productivity of plantations of the main forestforming species of Northern Eurasia (normative and reference materials). Moscow: Rosleskhoz (in Russian).

Slayback, D. A., Pinzon, J., Los, S. O., \& Tucker, C. J. (2003). Northern hemisphere photosynthetic trends 1982-99. Global Change Biology, 9, 1-15. https://doi.org/10.1046/j.13652486.2003.00507.x

Terentyev, A. Yu., Bala, O.P., \& Vladimirenko, V.M. (2008). Analysis of the growth forecast model according to the average height of artificial pine plantations in Polissya, Ukraine. Forestry and Forest Melioration, 113, 55-60. Retrieved from http://forestry-forestmelioration.org.ua/index.php/journal/ issue/view $/ 20$

Usoltsev, V. A. (1985). Modeling of structure and dynamics of phytomass of stands. Krasnoyarsk: Krasnoyarsk University Press (in Russian).

Usoltsev, V. A. (1988). Growth and structure of phytomass of stands. Novosibirsk: Science (in Russian).

Vasilishin, R. D. (2013). The course of growth of full fir stands in the Ukrainian Carpathians. Scientific Bulletin of NLTU, 23.6, 87-92.

Weiskittel, A. R., Hann, D. W., John, J., Kershaw, A., \& Vanclay, J. K. (2011). Forest Growth and Yield Modeling. WileyBlackwell. 